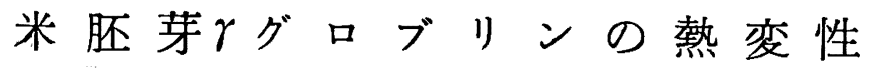

\author{
堀越 昌子*, 上杉 外勢*, 林 宏子*, 森田 雄平** \\ * 滋賀大学教育学部家政科 $* *$ 京都大学食糧科学研究所
}

\section{Heat Denaturation of $r$ Globulin of Rice Embryo}

\author{
Masako Horikoshi*, Tose Uesugi*, Hiroko Hayashi*, Yuhei Morita** \\ *Faculty of Education, Shiga University, Otsu-shi, Shiga \\ **Research Institute for Food Science, Kyoto University, Uji-shi, Kyoto
}

J. Jap. Soc. Food and Nutr., 25 (7), 561 564 (1972)

\begin{abstract}
The denaturation of $r$ globulin of rice embryo by heating was investigated. The viscosity of $r$ globulin from rice embryo increased markedly by heating the solution at $80^{\circ} \mathrm{C}$ for $30 \mathrm{~min}$. By heating at $100^{\circ} \mathrm{C}$ for $30 \mathrm{~min}$, gelation was observed. Accompanying with the increase in the viscosity, the detectable sulfhydryl groups of $r$ globulin increased markedly. The process apparently exhibited two steps. In comparison with heat denaturation, the effect of urea at room temperature was found to be milder and the conformation change appeared to be reversible.

Calcium ions stimulated heat denaturation and gelation of $r$ globulin solution. By heat-treatment at $70^{\circ} \mathrm{C}$ for $30 \mathrm{~min}$ with calcium ion, the viscosity and sulfhydryl groups of $r$ globulin rapidly increased. At $80^{\circ} \mathrm{C}$ with calcium ion, the change of the exposed sulfhydryl groups appeared within 3 min, and the protein partially precipitated.

These facts suggest that the heat denaturation was more drastic and irreversible, and the structural change of the protein should involve the unfolding of the peptide chains as well as the destruction of the subunit dissociation.
\end{abstract}

(Received May 27, 1972)

米穀粒中には, アルブミン, グロブリン, プロラミン およびグルテリンのたん白質が含まれている。これらの らちグロブリンは棣および胚芽に多く含有されて括り， 超遠心的に $\alpha, \beta, \gamma, \delta$ の 4 種に区別できる1)。7S の沈降

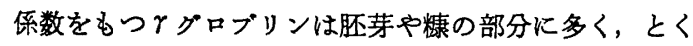
に肧芽グロブリンの $80 \%$ を占め, 生化学, 植物生理学 上で興味あるたん白質であるばかりでなく，米たん白質 の高度利用の観点からみても重要な研究対象であろう。 このたん白質は沢井, 森田 $\left.{ }^{2}\right)$ の研究によって $\gamma_{1}, r_{2}, r_{3}$ グロブリンの 3 成分から構成されていることが明らかに

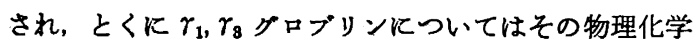
的性質や化学組成, 高次構造などが明らかにされた ${ }^{3) ~ 6) 。 ~}$ 本報では米たん白質の高度利用開発を目的として, 米

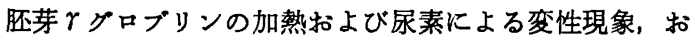
よびこれに及ぼすカルシウムイオンの影柿を検討し，変 性に伴ら

\section{実験方 法}

\section{1. 材 料}

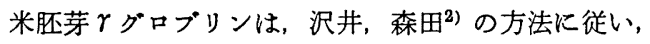
1970年度産米胚芽から調製した。すなわち米胚芽の抽出 液から水透析によりグロブリン画分を調製し，このうら の $0.27 \mathrm{M}$ 塩化ナトリウム溶液可溶画分からセファデッ クスG-200によるゲル濾過クロマトグラフィーによって 精製した。このものは組成分として約等量の $r_{1}, r_{2}$ グロ ブリンを含有している。

実験にはとくに記载しない限り $0.8 \mathrm{M}$ 塩化ナトリウム を含有する $0.08 \mathrm{M}$ リン酸塩緩衝液 ( $\mathrm{pH} 6.84)$ に溶解し たてグロブリン溶液を使用した。たん白質濃度は銅 Folin 法と $280 \mathrm{~m} \mu$ での吸光度測定法とを組み合わせて 行ない, $r$ グロブリンの $280 \mathrm{~m} \mu$ での吸光係数, $E_{1 \%}^{1 \mathrm{~cm}}$ $280 \mathrm{~m} \mu$ は 7.2 の値を用いた。

* $=520$ 滋賀県大津市石山平津町 197

** 个 611 京都府宇治市五ヶ庄 


\section{2. 粘度測定}

Ubbelohde 粘度計を使用し, $20^{\circ} \mathrm{C} \pm 0.01^{\circ} \mathrm{C} て ゙$ 粘度を測 定した。0.8 M 塩化ナトリウムー0.08 M リン酸塩緩衝液 (pH 6.84) $2 \mathrm{~m} l$ が流下する時間は 126.5 秒であった。

3. スルフヒトリル基（SH 基）の定青

Ellman7) の方法に従い,たん白質溶液に $5,5^{\prime}$-ジチオ ビスー(2-ニトロ安息香酸) 試薬を加え, 2 分後に $412 \mathrm{~m} \mu$ の吸光度を測定した。定量には pH 8.0 での分子吸光係 数, $\varepsilon=13,600$ の值を使用した。なお尿素はスルフヒド リル基の定量を妨害しないので尿素を除かず測定した。

\section{実 験 結 果}

\section{1. 加熱処理による比粘度と $\mathrm{SH}$ 基の变化}

ケグロブリンの $0.5 ， 1.0 １ .5 ， 2.0 \%$ 溶液をそれぞ れ $20,40,60,70,80,100^{\circ} \mathrm{C} て ゙ 30$ 分間処理したのち 粘度を測定した。その結果の一部をFig. 1 に示した。

この図からケグロブリンの粘度は, $80^{\circ} \mathrm{C} 30$ 分間加熱 処理のとき急激に増加していることがわかる。100 $\mathrm{C}$ 加 熱処理では，たん白質溶液は半透明ゼラチン状のゲル化 を括こす。たん白質濃度が高いほど粘度の増加率は高く $1.5 \%, 2.0 \%$ 溶液では $80^{\circ} \mathrm{C}$ 処理で一部沈殿が生成した。

これらの結果から， 急速な変性にともない粘度増加を起こしていることがわ かるが，これは分子内の水素結合，静電結合などで保持 された高次構造が熱運動により破壊され，たん白質分子 の伸張を引き起こすためであると考えられる。またたん 白質濃度が高いほど粘度増加率が高く，不溶化しやすい のは，伸張したたん白質分子の相互作用がより起こりゃ

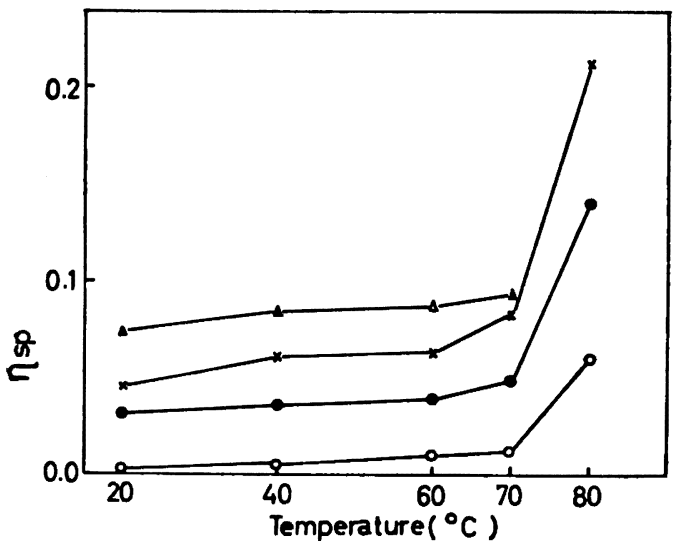

Fig. 1. Specific viscosity of $\gamma$ globulin solution after heat-treatment for $30 \mathrm{~min}$.

Protein concentration: $-0-0.5 \%,-\times-1.5 \%,-0-1.0 \%$, $-\triangle-2.0 \%$

Viscosity measurements were carried out with an Ubbelohde viscometer having the flow time of 126.5 seconds with $2 \mathrm{ml}$ of $0.08 \mathrm{M}$ phosphate buffer containing $0.8 \mathrm{M}$ sodium chloride $(\mathrm{pH} 6.84)$ at $20 \pm 0.01^{\circ} \mathrm{C}$.

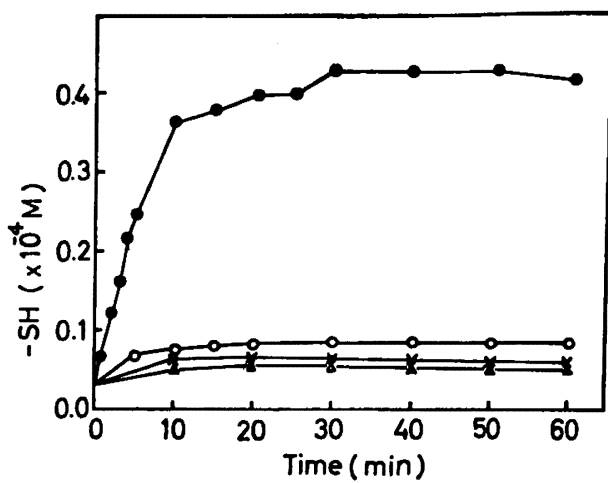

Fig. 2. Changes in amount of $\mathrm{SH}$ groups of $r$ globulin after heat-treatment.

Protein concentration : $0.05 \%$

Heat-treatment : $-\Delta-40^{\circ} \mathrm{C},-0-70^{\circ} \mathrm{C},-\times-60^{\circ} \mathrm{C},-8-80^{\circ} \mathrm{C}$ The DTNB reagent $(0.025 \mathrm{ml})$ was added to $3 \mathrm{ml}$ of $\gamma$ globulin solution ( $\mathrm{pH} \mathrm{8.0)}$ and the absorbance at $412 \mathrm{~m} \mu$ was measured after $2 \mathrm{~min}$. Results were expressed as moles $(\mathrm{SH})$ using the molecular extinction coefficient $(13,600 / \mathrm{M} / \mathrm{cm})$.

すいためであろう。さらに $100^{\circ} \mathrm{C}$ 処理でのゲル化は高温 で急速に伸張したたん白質分子が相互に網目状の会合を 起こしたためと考えられる。

このようなケグロブリンの熱変性は検出される S H基 数の変化からも追跡できる。Fig. 2 は $0.05 \%$ ゲロブ リンについて加熱処理を行ない，検出される S H 基数を 経時的に追跡した実験結果を示してある。

すなわち $80^{\circ} \mathrm{C}$ 加熱処理で分子内部にうずまっていた S H基が，急速に分子表面にあらわれており，この現象 は加熱処理による粘度の上昇現象とよく一致している。 経時的には S H 基の露出は $80^{\circ} \mathrm{C}$ 加熱 $0 \sim 10$ 分, 10〜30 分の 2 段階で起こっており，1段階目で $85 \%$ が，あと の $15 \%$ は 2 段階目で分子表面にあらわれている。

なお比較のために，各種濃度の尿素共存下で検出でき る S H基数の経時変化を測定した結果を Fig. 3 K示し た。図よりケグロブリンは $4 \mathrm{M}$ 尿素濃度では徐々に S H 基数が増加するのに対し，6M 以上の尿素濃度では最初 の 1 ～ 2 分間で急激に増加し，ついでわずかに減少する ことがわかる。この場合に出現する S H 基の数は $80^{\circ} \mathrm{C}$ 加熱処理の場合の約半量である。また $6 \mathrm{M}, 8 \mathrm{M}$ 尿素涶 度で20分間処理した $\gamma$ グロブリン溶液を $0.8 \mathrm{M}$ 塩化ナト リウム $-0.03 \mathrm{M}$ リン酸塩緩衝液（pH 8.0）に対して一 夜透析して尿素を除き S H基数を調べてみると，尿素添 加前の S H基数と一致していた。

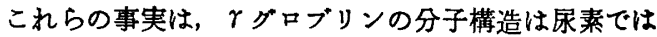
完全には破壊されず，かつ変性は可逆的であるのに対し $80^{\circ} \mathrm{C}$ 加熱処理では分子構造が修復のきかないほど破壊さ れ，不可逆的な変性をうけることを示唆している。 


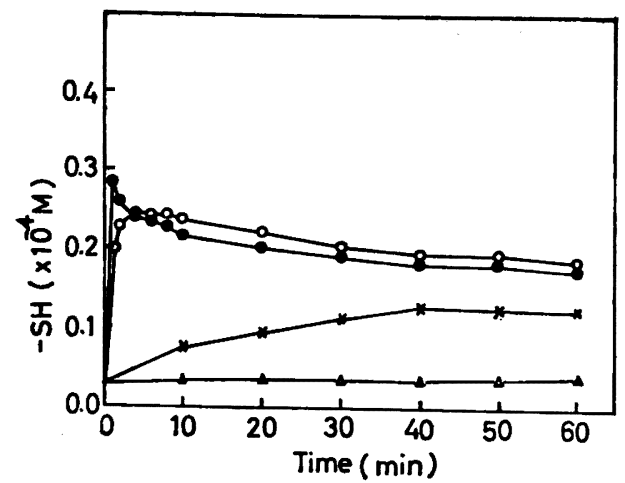

Fig. 3. Changes in amount of SH groups of $r$ globulin after urea-treatment.

Protein concentration : $0.05 \%$

Urea concentration : $-\Delta-2 \mathrm{M},-\mathrm{O}-6 \mathrm{M}-, \times-4 \mathrm{M},-\bullet-8 \mathrm{M}$

\section{2. 加熱変性におよばすカルシウムイオンの影暗}

ケグロブリンの熱変性現象が, カルシウムイオンの存 在でどのよらに影響されるかを調べた結果の一部を示す と Fig. 4 のと拈りである。実験はたん白質濃度 $0.5 \%$, カルシウムイオン濃度 $1,10,100 \mathrm{mM}$ で行なった。

この四から， ケグロブリンの粘度はカルシウムイオン が存在すると, $70^{\circ} \mathrm{C} 30$ 分間加熱処理で急激な上昇を起 こしていることがわかる。またカルシウムイオンが多い ほど粘度上昇は著しく，カルシウムイオン $100 \mathrm{mM} 80^{\circ} \mathrm{C}$ 処理では, ゲル化を抗こし，1，10 mM の場合です一部 不溶化を接こした。カルシウムイオンにより粘度上昇,

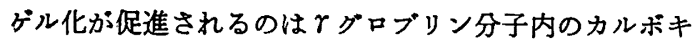
シル基や水酸基とカルシウムイオンが結合することによ って加熱処理による unfolding の平衡を，分子を変性さ せる方向にずらし，つぎつぎ伸張した分子間で会合をお

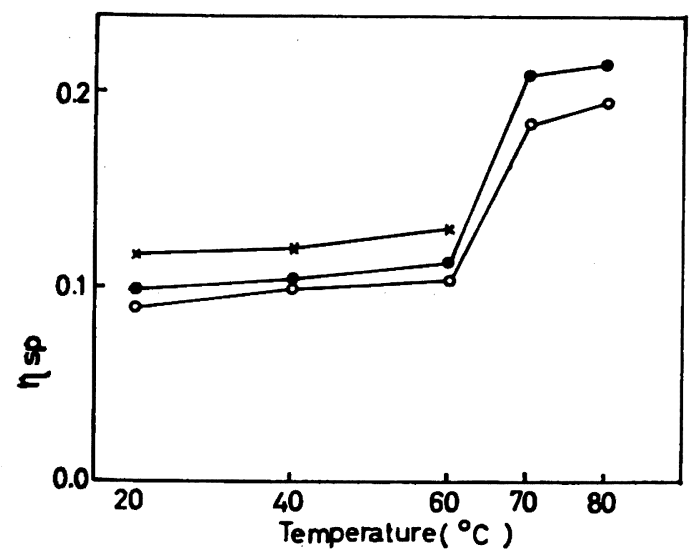

Fig.4. Specific viscosity of $\gamma$ globulin solution after heat-treatment for $\mathbf{3 0} \mathrm{min}$ with calcium ion.

Protein concentration : $0.5 \%$

Calcium ion concentration : $-O-1 \mathrm{mM},-\bullet-10 \mathrm{mM}$, $-x-100 \mathrm{mM}$

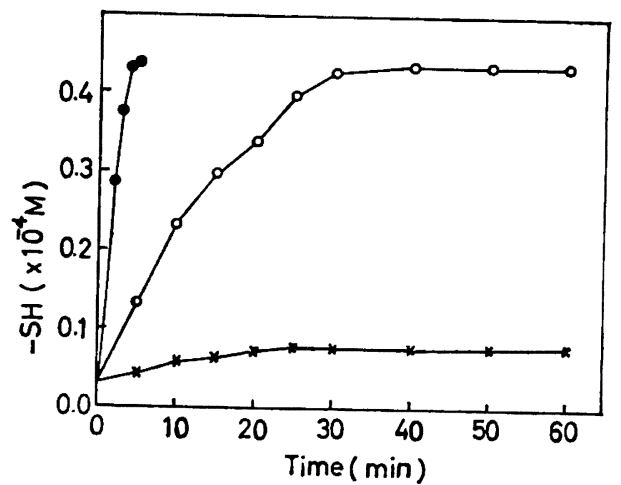

Fig. 5. Changes in amount of $\mathrm{SH}$ groups of $r$ globulin after heat-treatment with calcium ion.

Protein concentration : $0.05 \%$

Calcium ion concentration : $10 \mathrm{mM}$

Heat-treatment : $-\times-60^{\circ} \mathrm{C},-0-70^{\circ} \mathrm{C},-\bullet-80^{\circ} \mathrm{C}$

こしていくからと考えられる。

このようなカルシウムイオンの効果は S H 基出現数を 追跡しても明らかに認められる。Fig. 5 に示すと怙り， $r$ グロブリンの分子内 $\mathrm{S} \mathrm{H}$ 基はカルシウムイオン $10 \mathrm{mM}$ 存在下では, $70^{\circ} \mathrm{C}$ 加熱処理ですでに分子表面にあらわれ るが，これはカルシウムイオンが存在しないときの80C 加熱処理にほぼ相当している。カルシウムイオン存在下 での $80^{\circ} \mathrm{C}$ 加熱では最初の 3 分間で急速に S H 基が分子 表面にあらわれ，それ以上の加熱では不溶化が起こっ た。これらの結果はカルシウムイオン存在下の粘度上昇 現象とよく一致しておりカルシウムイオンはケグロブリ ンの熱变性を促進させる効果をるつことを示している。

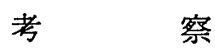

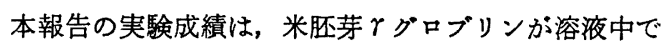
$80^{\circ} \mathrm{C} 30$ 分加熱処理により変性をうけ,これに伴って溶 液の粘度をまし，また検出される S H 基の量が著しく増 大することを示した。尿素変性との比較を行なった結果 では，熱変性の方がはるかに大きい構造変化を伴いかつ 不可逆であることが特改である。

さきに沢井，森田礼は精製した $\gamma_{1}$ グロブリンの尿素变 性を超遠心分析, 紫外領域での差吸収スペクトル測定, $\mathrm{S} \mathrm{H}$ 基滴定, ポリアクリルアミド電気泳動法などを用い て詳細に研究した結果, 種々の物性は尿素溶液約 $4 \mathrm{M}$ に 変移点をるち，これが主として四次構造の破壊すなわち subunit への解離に伴う現象であることを明らかにする とともに S H基, カルボキシル基拉よび蹯水結合が高次 構造維持に重要な役割を果たしていることを示唆した。 しかしながらこのよらな尿素変性は，分子の大きさやS $\mathrm{H}$ 基滴定数からみる限りでは可逆的である。これに対し て尿素よりすさらに強力な変性剤塩酸グアニジンの作用 
は，rグロブリンのより大きな構造変化をるたらし，し かもこの変化は 2 段階であってかつ不可逆的である。今 回報告した加熱処理による変性もこれに似て構造変化が 大きくまた不可逆的である。これは塩酸グアニジンや加 熱処理が, 四次構造の破壊ばかりでなく二次, 三次構造の 大きな変化を伴い， しかもある中間段階を経て天然のも のとは違った準安定構造に転移するのであろう。

これは尿素変性の場合は主として疎水結合の破壊をも たらすのに対し，加熱変性では水素結合やイオン結合の 破壞が主であり，熱運動によってこれらの不安定な結合 が破られ伸張した分子またはサブユニットが新たな柾水 結合を形成して，天然とは違ったある準安定な構造を形 成するのであろう。新たな結合は，たん白質濃度が低い ときには主として分子内部で起こるのに対し，たん白質 濃度が高いときには相互に凝集して不溶化を起こす。

また $100^{\circ} \mathrm{C}$ 処理のようにきわめて急速な変性の場合に は, 分子間の不安定な結合が優先してゲル化を起こすも のと考えられる。すちろん好気的な条件下で長い間にわ たる処理をすれば分子間に S S 結合を生じて不溶化, ま たはゲル化が促進されるのはいらまでもない。

沢井，森田 ${ }^{4}$ が尿素変性において水素イオン濃度によ って促進されることを示したこと，扣よび今回の実験で カルシウムイオンが熱変性を促進することは，いずれる rグロブリン分子中の陰性荷電の減少と変性促進との関 連性を示唆している。これはイオン結合の破壊や解離し たカルボキシル基と水酸基との間の水素結合の破壊が分 子構造変化を促進することを示している。どのよらな結 合がどの程度分子構造の保持に寄与しているかは, さら に詳細な熱力学的研究にまたねばならない。

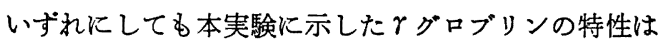
比較的希薄な溶液についての成績であるけれども，これ らの特性は未変性の成分たん白質 $\gamma_{1}, \gamma_{2}, \gamma_{3}$ グロブリン の特性とともに，大豆グロブリン $7 \mathrm{~S}$ おび $11 \mathrm{~S}$ 成分た ん白質の特性と, きわめて類似していることがわかる8)。 ケグロブリンの高度利用を目的とする場合は，大豆た ん白質について得られているような高濃度での変性現 象9) 11) や倲結1213), 乾燥 ${ }^{14)}$ に伴亏物性変化に関する重 要な問題であるので, 今後大豆たん白質と比較しながら これらの問題を研究する予定である。

$$
\text { 要 約 }
$$

1）米胚芽 $\gamma$ グロブリン溶夜の粘度は $80^{\circ} \mathrm{C} 30$ 分間の 加熱処理で急激に増加し， $1.5 \%$ 以上の濃度では一部不

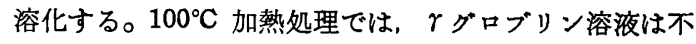
可逆的なゲル化を括こす。

2） $r$ グロブリンの分子内部の $\mathrm{S} \mathrm{H}$ 基は， $80^{\circ} \mathrm{C}$ 加熱処 理で急速に分子表面にあらわれる。その反応は最初の10
分間で $85 \%$ まですすみ，あとの $15 \%$ はその後の 20 分 間で分子表面にあらわれる。

3） $r$ グロブリンの尿素変性では，分子内の $\mathrm{S} \mathrm{H}$ 基は 尿素濃度 $6 \mathrm{M}$ で最初の 3 分間に, $8 \mathrm{M}$ 濃度では 1 分間に 分子表面に現われ，その後徐々に減少する。加熱変性の 場合と比べると分子表面にあらわれる S H 基数は最大限 で約半数であり尿素を除いたあとの S H 基は減少する。

4）カルシウムイオンが存在すると，rグロブリン客 液の粘度は, $70^{\circ} \mathrm{C} 30$ 分間加熱処理で顕著に上昇する。 カルシウムイオンは多いほど粘度上昇は著しく，1，10 $\mathrm{mM}$ カルシウム濃度で $80^{\circ} \mathrm{C}$ 亿加熱すると一部不溶化し, $100 \mathrm{mM}$ の濃度ではゲル化を起こす。

5）カルシウムイオンが存在するときのアグロブリン 内部の $\mathrm{S} \mathrm{H}$ 基は, $70^{\circ} \mathrm{C}$ 加熱処理で分子表面飞あらわれ る。これはカルシウムイオンがないときの $80^{\circ} \mathrm{C}$ 加熱処 理にほぼ相当する。カルシウムイオン存在下の $80^{\circ} \mathrm{C}$ 加 熱では最初の 3 分間で急速に S H 基が分子表面にあらわ れ，それ以上の加熱では一部不溶化する。

本研究にあたり，材料を提供された大倉酒造および有 益な助言をいたたいた藤沢薬品工業株式会社沢井秀樹博 土に潹く感謝する。

\section{文献}

1) Morita, Y. and Yoshida, C.: Agr. Biol. Chem., 32, 664 (1968)

2) Sawai, H. and Morita, Y.: Agr. Biol. Chem., 34, 53 (1970)

3) Sawai, H. and Morita, Y.: Agr. Biol. Chem., 34, 61 (1970)

4) Sawai, H. and Morita, Y.: Agr. Biol. Chem., 34, 771 (1970)

5) Morita, Y., Sawai, H., Hamaguchi, K. and Ikeda, K.: Agr. Biol.Chem., 35, 1231 (1971)

6) Morita, Y. and Horikoshi, M. : Agr.Biol.Chem., 36, 651 (1972)

7) Ellman, G. L.: Arch. Biochem. Biophys., 82, 70 (1959)

8) Wolf, W. J. and Tamura, T.: Cereal Chem., 46, 331 (1969)

9) Catsimpoolas, N. and Meyer, E. W.: Cereal Chem., 47, 559 (1970)

10) Catsimpoolas, N. and Meyer, E. W.: Cereal Chem., 48, 150 (1971)

11) Catsimpoolas, N. and Meyer, E. W.: Cereal Chem., 48, 159 (1971)

12) Hashizume, K., Kakiuchi, K., Koyama, E. and Watanabe, T.: Agr. Biol. Chem., 35, 449(1971).

13) Saio, K., Kajikawa, M. and Watanabe, T.: Agr. Biol. Chem., 35, 890 (1971)

14) Fukushima, D. and Buren, J. V.:Cereal Chem., 47, 687 (1970)

（昭和 47 年 5 月 27 日受理） 